\title{
Epistemic communities and cluster dynamics On the role of knowledge in industrial districts
}

\author{
Håkanson, Lars
}

Document Version

Final published version

Publication date:

2003

\section{License \\ CC BY-NC-ND}

Citation for published version (APA):

Håkanson, L. (2003). Epistemic communities and cluster dynamics: On the role of knowledge in industrial districts.

Link to publication in CBS Research Portal

\section{General rights}

Copyright and moral rights for the publications made accessible in the public portal are retained by the authors and/or other copyright owners and it is a condition of accessing publications that users recognise and abide by the legal requirements associated with these rights.

\section{Take down policy}

If you believe that this document breaches copyright please contact us (research.lib@cbs.dk) providing details, and we will remove access to the work immediately and investigate your claim. 


\title{
EPISTEMIC COMMUNITIES AND CLUSTER DYNAMICS: ON THE ROLE OF KNOWLEDGE IN INDUSTRIAL DISTRICTS
}

\author{
Lars Håkanson \\ Department of International Economics and Management \\ Copenhagen Business School \\ Howitzvej 60, DK-2000 Frederiksberg, Denmark \\ Phone: +45 38152515 Fax: +45 38152500 Email: lh.int@cbs.dk
}

October 2003

En earlier version of this paper was presented at the DRUID Summer Conference 2003 on CREATING, SHARING AND TRANSFERRING KNOWLEDGE.

The role of Geography, Institutions and Organizations.

Copenhagen June 12-14, 2003 


\title{
EPISTEMIC COMMUNITIES AND CLUSTER DYNAMICS: ON THE ROLE OF KNOWLEDGE IN INDUSTRIAL DISTRICTS
}

\begin{abstract}
This paper questions the prevailing notions that firms within industrial clusters have privileged access to 'tacit knowledge' that is unavailable - or available only at high cost - to firms located elsewhere, and that such access provides competitive advantages that help to explain the growth and development of both firms and regions. It outlines a model of cluster dynamics emphasizing two mutually interdependent processes: the concentration of specialized and complementary epistemic communities, on the one hand, and entrepreneurship and a high rate of new firm formation on the other.
\end{abstract}




\section{Introduction}

In recent literature on the economic geography of clusters, it has become conventional to emphasize the seeming contradiction between 'globalization', on the one hand, and the continued importance of geographic location and regional advantage, on the other (see, e.g., Markusen, 1996; Porter, 1998; Maskell, 2001; Narula, 2003). Clusters, so the argument goes, are worthy of renewed attention not only because of their obvious economic and social significance, but also because globalization has made the problems they pose to economic theory more puzzling. Why is it, precisely, that - in spite of dramatic reductions in communication and transportation costs - firms in some locations appear to be systematically more innovative, more productive and more dynamic than in others?

In addressing this question, this paper questions some of the prevailing notions regarding the nature and definition of clusters, the mechanisms by which they emerge and prosper and the advantages they confer to firms. The argument is based on a complementary and, I shall argue, more useful way of defining clusters than that commonly employed. Rather than seeing clusters primarily as concentrations of interlinked industries, producing similar or complementary outputs, it is instructive to recognize that they are also agglomerations of professionals, i.e. practitioners belonging the same or related epistemic communities (Loasby, 1998).

This change in perspective puts in a different light the nature of the advantages that clusters may provide. In summarizing the argument in a simple model of cluster dynamics, I shall argue that we need to recognize - more clearly than is usually done - that the logic of the system, i.e. the cluster, is different from that driving the behavior and performance of its components, i.e. the individuals and firms of which it is formed. Indeed, the latter cannot be deduced from the former. Doing so obscures the nature of the causal links between co-located economic activities as empirically observed (cf. Markusen, 1999).

\section{The prevailing view and its antecedents}

Until the early 1970s, the existence of 'industrial complexes' (as they were then known) was largely explained in terms of Weberian least cost calculations, where alternative locations were evaluated primarily on the basis of the cost and availability of capital, labor and physi- 
cal productive resources (Isard \& Schooler, 1959; Smith, 1971). However, with the dramatic reduction of transportation and communication costs, the inadequacy of this approach soon became increasingly obvious. By the middle of the decade, economic geographers and regional scientists - under the guise of 'industrial systems analysis' or 'geography of the firm' - began to search for alternative models and approaches. (See, e.g., Hamilton and Linge $(1979,1981)$ for interesting but seemingly forgotten contributions.) Shortly thereafter, the location of economic activity again (the pioneers in the study of localization of industry were all economists) attracted the interest also of scholars from other disciplines (Martin, 1999).

Increasingly, the literature on regional economics began to emphasize the way that, in some regions, flexible manufacturing systems and forms of network governance would permit firms to capture and exploit knowledge externalities (or, less elegantly, 'spillovers'). Elaborate and shifting divisions of labor, it is now commonly argued, enable firms to better cope with the uncertainty of rapidly changing technologies. This gives rise to dynamic economies of learning, enabling firms in certain regions to maintain and exploit technological advantages that are insensitive to shifts or differences in factor costs (Piore and Sabel, 1984; Storper and Harrison, 1991; Storper, 1992; Pouder and St. John, 1996; Asheim, 1996; Morgan, 1997; Porter 1998; Malmberg and Maskell, 1997; Maskell and Malmberg, 1999a, 1999b; Lawson, 1999: Lawson and Lawrence, 1999; Keeble and Wilkinson, 1999; Keeble et al., 1999).

It has been pointed out that this model of Marshallian industrial districts does not well describe all types of dynamic regional economies (Markusen, 1996). Nevertheless, there seems to be general agreement of its basic features and its perceived applicability to a wide range of regions in both Europe and North America - especially those dominated by industries where skill and variety (rather than, for example, scale) are key to competition (Storper, 1992).

Many of these regions have been objects of detailed case studies providing empirical support to some of the salient characteristics of the model, such as specialization and flexible network cooperation, high rates of new firm formation, product and process innovation, etc. Saxenian's seminal depiction of the networks in Silicon Valley is representative of the genre ${ }^{1}$ : 
It is not simply the concentration of skilled labor, suppliers and information that distinguish the region. A variety of regional institutions - including Stanford University, several trade associations and local business organizations, and a myriad of specialized consulting, market research, public relations and venture capital firms - provide technical, financial, and networking services which the region's enterprises often cannot afford individually. These networks defy sectoral barriers: individuals move easily from semiconductor to disk drive firms or from computer to network makers. They move from established firms to start-ups (or vice versa) and even to market research or consulting firms, and from consulting firms back into start-ups. And they continue to meet at trade shows, industry conferences, and the scores of seminars, talks, and social activities organized by local business organizations and trade associations. In these forums, relationships are easily formed and maintained, technical and market information is exchanged, business contacts are established, and new enterprises are conceived... This decentralized and fluid environment also promotes the diffusion of technological capabilities and understandings. (Saxenian, 1994, p. 96-97)

The quotation asserts a key assumption in the current literature on the economics of regional clusters, i.e. the importance of 'knowledge externalities'. The emphasis on 'knowledge' reflects both the declining relative importance of material inputs in many manufacturing industries (and the increasing role of service industries in the economy) and their increasingly ubiquitous nature - they are often available everywhere at nearly the same cost.

The invocation of 'external economies' to explain observed agglomerations of economic activity parallels Alfred Marshall's classical treatment more than a century ago. Although not giving them so much emphasis as is today common, Marshall, along with economies of specialization, intermediate goods supply and labor market economies, in a much-quoted passage also discussed the influence of 'knowledge externalities'?

When an industry has thus chosen a locality for itself, it is likely to stay there long; so great are the advantages which people following the skilled trade get from near neighbourhood to one another. The mysteries of the trade become no mysteries; but are as it were in the air... Good work is rightly appreciated, inventions and improvements in machinery, in processes and the general organization of the business have their merits promptly discussed: if one man starts a new idea, it is taken up by others and combined with suggestions of their own; and thus it becomes the source of further ideas. (Marshall, 1920, p. 271)

In Marshall's time - on the eve of the introduction of the telephone but long before the advent of modern communication technologies - it was natural to emphasize the importance of proximity and word-of-mouth communication for the spread and exchange of new ideas. The spatially bounded nature of knowledge needed no further explanation. 
Today, in a world of searchable databanks and instantaneous Internet connections, the role of geographical distance for the diffusion of knowledge is no longer so obvious. Indeed, the misleading view has become prevalent that, as soon as knowledge becomes articulated and put into code, distance no longer matters to its diffusion. In order to explain the observed continued importance of 'localized knowledge spillovers', (see, e.g. Jaffe et al., 1993; Antonelli, 1994; Audretsch and Feldman, 1996; and the survey by Feldman, 1999) it has become customary to invoke the obscurant concept of 'tacit knowledge'. As a prominent exponent of this view puts it:

...[T]he propensity for innovative activity to cluster spatially will be the greatest in industries where tacit knowledge plays an important role. ... it is tacit knowledge, as opposed to information, which can only be transmitted informally, and typically demands direct and repeated contacts. (Audretsch, 1998, p. 23)

Tacit knowledge is unarticulated, highly contextual and can only be transmitted in face-toface interaction or through the physical movement of individuals. Access to tacit knowledge is obtained through embeddedness in local networks. This notion has become so well established that, for Almeida and Kogut, for example, "[o]ne obvious reason why knowledge should be regional is that it is held tacitly by skilled engineers who remain within the region” (Almeida and Kogut, 1999, p. 907, italics added).

In view of the significance attached to the concept, remarkable little attention and effort have been devoted to improve our understanding of the nature of the 'tacit knowledge' believed to be floating around in clusters. ${ }^{3}$ If not sooner, this issue acquires certain urgency as one tries to picture a group of engineers (and other cluster members) exchanging knowledge that can neither be expressed in words nor in other, more specialized code. How do they go about it? And what sorts of economically significant skills require for their exercise the possession of tacit knowledge?

\section{Tacit Knowledge and Local Knowledge Spillovers}

\section{The Role of Tacit Knowledge in Contemporary Theory of Clusters}

Not only in economic geography but in several other strands of literature, the notion of 'tacit knowledge' - knowledge that is important but cannot be expressed in words - has gained widespread currency over the past decade (Cowan et al., 2000). However, the vagueness of the concept and the readiness with which it has been accepted without a clear understanding or consensus as to its meaning have served as an invitation to obscurantism (Håkanson, 
2003). Indeed, it has confused more than elucidated our understanding of the dynamics of knowledge processes in industrial districts (and in other settings).

The prevailing view on the importance of 'localized knowledge' is based on a few deceptively simple assumptions, such as the idea that knowledge comes in two varieties: codified and tacit. ' 'Codified knowledge' is knowledge that has been (or could be - the important distinction is rarely made) rendered in writing or other code and can be transmitted by means not requiring personal contact. ${ }^{5}$ "Tacit knowledge" is usually defined as the negation of its "codified' variety, generally with a standard reference to Polanyi’s (1966, p. 4) dictum - "we can know more than we can tell”. 6

Codified knowledge, it is assumed, "flows" (nearly) without friction and (nearly) without cost. This facilitates voluntary replication and technology transfer but increases the risk of involuntary imitation (Winter, 1987):

Any codification of a piece of knowledge will eventually lead to its diffusion, thereby undermining the present possessor's possibility of using it as an ingredient in sustaining competitiveness... When formerly tacit knowledge is converted into a fully codified form, a process is initiated which will sooner or later - usually sooner - turn it into a ubiquity by making is accessible on the global market. (Maskell and Malmberg, 1999b, p. 16)

'Tacit knowledge', therefore, attains special significance because, following von Hippel’s (1994) metaphor, it is supposed to be spatially 'sticky'. The assumption that it cannot, or cannot easily (depending on the point of view of the author) be articulated and codified suggests that it can only be acquired through experience - archetypically in master-apprentice types of relationship, such as the 'legitimate peripheral learning' described by Lave and Wenger (1991). One would expect, therefore, that its short-run diffusion would take place largely through the movement of skilled personnel (Zucker et al., 1998; Almeida and Kogut, 1999).

However, by some unexplained magic, it is assumed that “... where firms share the same values, background and understanding of technical and commercial problems, a certain interchange of tacit knowledge does in fact take place” (Maskell and Malmberg, 1999a, p. 172). According to this line of argument, tacit knowledge can be “exchanged” locally but, being tied to a specific social context, it is difficult or impossible to transfer over long distances. ${ }^{7}$ Its exchange requires that partners share commonalities of language and beliefs, both regarding the nature of the technical and commercial realities that they confront and the rules that are 
expected to govern their interaction. Conversely, 'codified knowledge' can be easily accessed by everyone, regardless of location, and, in consequence, "one effect of ongoing globalization is that many previously localized capabilities and production factors become ubiquities" (Maskell and Malmberg, 1999a, p. 172).

The argument is based on the notion that whereas tacit knowledge is difficult to both to imitate and to voluntarily replicate, the converse is true for articulated knowledge which can therefore, it is believed, only provide momentary competitive advantage, at best (Winter, 1987). In its crudest form, it suggests that knowledge can be dichotomized into "tacit or easily imitated” (Almeida and Kogut, 1999, p. 907).

The prominence that this line of reasoning has come to enjoy is curious. First, it implicitly equates 'articulation' with 'codification' - with the articulation of knowledge follows, automatically as it were, its codification into fixed, standardized, and easily replicable form. In reality, codification is a time and resource demanding activity, the potential benefits of which are often unclear. Unsurprisingly, therefore, the time between initial articulation of knowledge and its eventual codification can be quite long (Murtha et al., 2001). Indeed, in the absence of relevant incentives, it is probable that some articulated knowledge never becomes codified.

Second, it assumes that the proprietor of articulated knowledge is unable to protect its dissemination. This, in turn, assumes that potential imitators rapidly learn about the existence of the knowledge in question, are familiar with the underlying theory, have access to the requisite tools and master the code in which the knowledge is expressed. Moreover, by some legal or illegal means - precisely which are never spelled out - they can then obtain access to the knowledge and exploit it in ways that are harmful to its original owner. In reality, of course, there are many ways in which firms can successfully protect their codified knowledge, including among the obvious ones, industrial secrecy and patenting. Furthermore, knowledge only becomes economically significant when it serves to inform the successful exercise of a skill. Usually, performance improves with practice and experience. Having access to the same codified knowledge is sometimes - but not always - enough to permit the skilled execution of the practice that it informs (Winter and Szulanski, 2001). 
But the converse is not true either. The assumption that skills based on tacit knowledge are more or less inimitable presupposes that a potential imitator, although mastering all other aspects of the skill or activity in question, does not share, cannot draw on or create whatever tacit understanding may be involved in its execution. In reality, the employees of firms in the same industry tend to share much of the tacit knowledge that their practice requires. This puts them in a position where they can often imitate one another's advances by simple trial and error, without necessarily having access to codified descriptions of these advances.

The argument is implausible not only on theoretical grounds. Although admittedly scant, the empirical evidence available does not support it. In Zander's study (Zander, 1991; Zander and Kogut, 1995), the degree of codifiability and articulability of manufacturing technology did not significantly increase the risk of early imitation. McEvily and Chakravarthy (2002) found that 'tacitness' increased the time to imitation for major product innovations but that it significantly decreased it for minor product improvements.

\section{Epistemic Communities and Cluster Dynamics}

The Contextual Nature of Knowledge

The argument, as outlined above, is correct in emphasizing the fact that all knowledge is context-dependent. Indeed, neither tacit nor explicit knowledge can be defined without reference to the community where it resides. However, such communities are not only, and not primarily, formed through the social interaction that geographical proximity affords. More importantly, epistemic communities and their defining knowledge emerge in the common pursuit of a common practice. ${ }^{8}$

All knowledge requires for its meaningful interpretation and effective application mastery of the codes (language, vocabulary, symbols etc.) in which it is expressed, at least intuitive understanding of the theories (implicit and explicit cognitive frames, beliefs, mental maps, etc.) to which it refers, as well as familiarity in the use of the tools of the associated practice (Håkanson, 2003). Each and all of these knowledge elements typically display some degree of local variation, and such idiosyncrasies can, sometimes severely, impede communication. ${ }^{9}$ By and large, however, knowledge exchanges are less cumbersome between people who belong to the same epistemic community than between individuals lacking a common cognitive background. Electronic engineers from different countries more easily communicate about the details of their work than they do with their local company controllers. 
The fact that knowledge moves with relative ease within epistemic communities - codified knowledge through the exchange of documents and other artifacts, tacit knowledge through emulation and imitation - but with relative difficulty between them has fundamental implications for the ease with which knowledge (both tacit and otherwise), can be transferred to and replicated in other locations and contexts than where it was first created. This, as I shall argue below, has implications for the significance and operations of industrial clusters.

\section{On the Definition of Clusters}

“Clusters,” Michael Porter argues, in a much-quoted article,

... represent a kind of new spatial organizational form in between arm's-length markets on the one hand and hierarchies, or vertical integration, on the other. A cluster, then, is a new way of organizing the value-chain... A cluster of independent an informally linked companies and institutions represents a robust organizational form that offers advantages in efficiency, effectiveness, and flexibility. (Porter, 1998, p. 79)

In spite of what the quotation might suggest, the emergence of clusters is not widely recognized as a Harvard Business School discovery, or as a very recent phenomenon. However, many would concur with the idea that clusters consist of and are defined by the value-adding activities in a set of linked companies and institutions. Their co-location, it is assumed, permits the exploitation of 'locational economies,' savings that arise from the agglomeration of 'related' economic activities. 'Relatedness', as Richardson (1972) has pointed out, refers to two distinct situations, similarity and complementarity of activities, respectively. The latter typically refer to different stages of the value chain, the former to parallel value chain activities.

While important, the focus on 'industries' implied by the above definitions has tended to divert attention from the fact that clusters are not only comprised of firms producing similar or complementary outputs, but also of people who belong to the same professions, have similar jobs, formal training and types of on-the-job experience. To a considerable extent, they are familiar with and use the same theories, have the same or similar views of the world, use the same language and codes to describe it and know master the tools of their common trade or industry (Grabher, 1993). In short, they belong to the same, related or complementary epistemic communities formed around the exercise of specific professional practices. ${ }^{10}$ Such communities share both the explicit and the tacit elements of the knowledge that inform their 
practice. ${ }^{11}$ Proximity, in combination with shared codes and understandings, facilitates the exchange of ideas and, possibly, innovatory combinations (Camagni 1991). However, already emphasized, the basic elements of the practice (codes, theories and tools) are typically common to all industry practitioners, regardless of their locations.

Concentrations of epistemic communities within easy commuting distance favor the entrepreneurial formation of new ventures, some of which survive. The growth of successful startups creates demand for specialized skills and encourages individuals to undertake the requisite investment in education and training. It may also attract immigration of specialists from elsewhere.

Notice, however, that these and related labor market economies exist regardless of the characteristics of the knowledge (i.e. whether tacit or explicit) possessed by the workers in question (Lissoni, 2001). Notice also that there is no a priori way of knowing whether these economies are large enough to offset potential diseconomies, such as various types of congestion costs, etc. Moreover, and more fundamentally, to the extent that such economies operate, we must be careful in specifying at what systemic level - that of the cluster or that of the firm, that of the potential entrepreneur or that of the individual job seeker - that they operate. As elaborated below, much current theorizing - encouraged by flawed empirical methodology - has tended to overlook and obscure these important distinctions (Staber, 1996).

\section{Towards a Model of Cluster Dynamics}

For illustrative purposes, the model that I am about to propose takes it starting point in a study undertaken more than half a century ago. In 1950, William William-Olson made an investigation of the regional economy of that part of the province of Småland served by the regional railroad company Halmstad-Nässjö Järnvägar. As part of this study he developed the graph, one of the first of its kind, reproduced in Figure 1. It depicts the history of firm formations 1877-1945 in the metal, wood and leather industries through which was formed the industrial district of Anderstorp, an industrial area renowned for its economic vitality to this day.

INSERT FIGURE 1 ABOUT HERE 
The graph and the accompanying anecdotes illustrate a number of fundamental and still valid principles of cluster growth, made all the more evident by the relative simplicity of the situation of the time: By modern-day standards, the rate of technological change was modest. The railroad, built in the years 1877-1909 provided important economic stimulus by connecting the region to Sweden's main centers if population, but - again by modern day standards - it was by and large isolated from the world market. Moreover, Småland was a famously barren part of Sweden, devoid of natural advantages, such as good transportation, farmland or valuable raw materials - except for forests, of course, but that particular advantage applies to most of the country. Its main resource, as the graph brings out, was the ingenuity and industriousness of its inhabitants.

\section{Entrepreneurship and New Firm Formation}

The structure of the following discussion is summarized in the simple model set out in Figure 2. In this initial version, outside influences are - as in Anderstorp in the first half of the $20^{\text {th }}$ century - assumed to be negligible. However, the model recognizes the exogenous determinants of (largely domestic) demand in terms of the (1) overall rate of growth in the economy, and (2) the specific impulses from the development blocks (Dahmén, 1988) or industrie motrice (Perroux, 1988) driving the economy at any specific time. It also accepts, as exogenously given, the nature of the opportunities available within prevailing technological trajectories (Dosi, 1988; Kenney and von Burg, 1999).

\section{INSERT FIGURE 2 ABOUT HERE}

In the model, entrepreneurship and new firm formation provide the decisive impulse for economic growth and innovation (Malmberg and Maskell, 2002). This reflects both the experiences in Anderstorp in the first part of the last century, and that in other dynamic regions, such as Silicon Valley, during the last couple of decades (Schoonhoven and Eisenhardt, 1992). The details of the cultural, economic and psychological roots that account for local variations in the propensity to set up new firms are too complex to pursue here (Garvin, 1983; Kirchhoff 1994a; Klepper, 2001). ${ }^{12}$ But regardless of the exact nature of the motives that drive people at different times and in different parts of the world to set up their own businesses, the example of successful peers is likely to be important. The more start-ups in the proximity that are, or appear to be, demonstrably successful, the easier it will be to overcome the natural hesitancy to go into business of your own (Feldman, 2000a). ${ }^{13}$ 
Of course, and this should not be overlooked, entrepreneurs systematically overestimate their chances of success. Most new ventures are dissolved or go bankrupt. Very few ever become profitable propositions and even fewer grow to become large undertakings. However, from the point of view of cluster dynamics, the many failed ventures do not necessarily count. Clusters prosper when existing firms grow and a sufficient number of start-ups survive. The growth and dynamics of the industrial districts are not nearly as dependent on the success rate of new ventures as on the rate of new firm formation. One of the most fundamental flaws of most other studies of cluster dynamics is the tendency to make inferences on the basis solely of surviving enterprises, forgetting the large numbers of short-lived firms censored and unobserved because of early demise. In their study of start-ups in the semiconductor industry, Schoonhoven and Eisenhardt (1992) found that survival rates in Silicon Valley was no different from that of other regions - the key difference was the absolute number of new firms that were founded there. Of course, the problems created by censored data are always difficult to solve - but ignoring them in the present context clearly obscures the nature of the processes involved.

In striking contrast to the sweeping assumptions commonly made in the theoretical literature, available empirical evidence as to the influence both of clusters and of more general economies of agglomeration on the performance prospects of established firms and the survival chances of start-ups is surprisingly meager (Table 1). ${ }^{14}$ Conclusions as to the beneficial effects both of more general urbanization economies and those ascribed to the localization of related industries seem decidedly premature (Malmberg and Maskell, 2002; Feldman, 2000b). If anything, the evidence suggests that firms located outside the centers of their industries are oftentimes better off than their compatriots within. Overall, however, the relationship between location and performance appears to be weak and difficult to detect.

\section{INSERT TABLE 1 ABOUT HERE}

The key to cluster prosperity is the high gross rate of new firm formation - not, as typically assumed, the favorable conditions in such locations for new firm survival and growth. ${ }^{15}$ This would appear to be especially true in industries characterized by rapid technological change and high uncertainty as regards the feasibility of new technical solutions - the very conditions, in fact, that create favorable opportunities for spin-offs. Start-ups are frequently 
vehicles for introducing innovations and each can be seen as a "bet" on a particular technology or product solution. Regions with many start-ups will have more "bets" and will therefore be more resilient and flexible than those dominated by a few vertically integrated firms (Saxenian, 1994).

This is not to say that cluster locations confer no benefits, merely that those benefits accrue primarily to individual entrepreneurs. It cannot be assumed that they automatically apply to the firms they establish, or - if they do - that the corresponding advantages are not outweighed by congestion costs or other drawbacks.

This conclusion is at odds with conventional wisdom which is based on the assumption that (1) firms make informed location decisions, where the advantages and disadvantages of alternative locations are explicitly weighed against one another, and/or (2) that competition ensures that only firms in 'optimal' locations survive. As The Oxford Handbook of Economic Geography puts it: "Since... wages and land prices are higher in these [densely concentrated] regions, for firms to be willing to locate in industry centers it must be that such locations have higher productivity for some factors or lower cost for other factors “ (Hanson, 2000, p. 484, italics added). Unless one is prepared to accept that the many factors influencing the fortunes of firms (technology, design, managerial talent, marketing skills, etc.) must all be 'optimal', the significance attached to location is curious.

For the individual entrepreneur, a most important benefit of being located in a cluster is the good prospects of finding alternative employment following a (highly probable) failure of her venture. This and other potential benefits - such as easy access to specialized technical and managerial expertise - derive from the fact that cluster growth is associated with the development and gradual differentiation of specific, often highly specialized epistemic communities.

\section{Formation of Epistemic Communities}

Although spectacular exceptions confirm the rule, most new firms are set up by people who have gained experience by working for other firms, in the same or related industries. They therefore share and understand the basic knowledge, both tacit and explicit, needed in these industries. This knowledge encompasses not only technical knowledge regarding the qualities of raw materials, the characteristics and principles of production processes, etc. It also 
includes an understanding of market characteristics and customer needs. Unsurprisingly, therefore, the activities of most new firms are in one way or the other related to the activities of existing ones (Helfat and Lieberman, 2002). Indeed, the process of new firm formation can often be seen as one of gradual specialization, the rate of which is determined by the size and growth of the market, but also by perceived technological opportunities.

In principle, 'spin-offs' from existing firms into new ones fall in one or a combination of three categories: (1) horizontal diversification (serving customers with new products or quality of products) (2) vertical specialization (new divisions in the primary part of the value chain), and (3) spin-offs or new establishments of firms providing various kinds of specialist support functions, such as legal services, public relations, IT-services, etc. The larger and the more prosperous a cluster is, the more scope it will offer to exploit advantages of specialization. $^{16}$

The result of this process is the emergence of a regional production networks characterized by both vertical and horizontal disintegration. Such production systems avoid the dangers of lock-in entailed by vertical integration and asset specificity, especially important in the case of rapidly changing technologies characterized by high uncertainty (Storper, 1992; Foray, 1991).

For epistemic communities of professionals, the agglomeration of a large number of firms active in the same or adjacent industries reduces the costs of job search and of inter-firm mobility. Labor mobility within epistemic communities facilitates the flow of new information between firms. Especially for small firms and start-ups, this is likely to be more important than possible transactional economies (Angel, 2000).

The observed association between vertical disintegration and agglomeration is primarily due to the logic and dynamics of new firm formation and the subsequent inertia that ties firms to their original locations. As a rule, new firms are established where their founders' have previously worked and where they and their families live, their spouses work and their children go to school (Hendry and Brown, 1998; Romanelli and Schoonhoven, 2001; Feldman, 2000a). It is within this spatially bounded social sphere that the prospective entrepreneur has most of the contacts she draws on in assembling the physical and knowledge resources required for her venture (Eisenhardt and Schoonhoven, 1990; Schoonhoven and Eisenhardt, 1992). In 
most cases, this is also where the source of the business idea can be found; most market opportunities are discovered during previous work experience.

As a long stream of research has shown, successful product innovation requires good understanding of the needs and circumstances of prospective users. Here, proximity can be an advantage, especially for small firms where managerial attention is typically a scarce resource and minimizing cost and time of travel can be important.

However, it cannot be inferred that more optimal locations would not be available elsewhere, for example, where costs for land and labor are lower. Both cognitive and psychological barriers account for the tendency of firms to stick to their original locations. It is generally difficult, often impossible, to determine very precisely the impact of location on profitability, especially in relation to all other factors, whose effects are often both more visible and easier to influence. Moreover, as long as firms enjoy some competitive advantage, profits typically allow a certain degree of slack, thereby protecting top management - who may be unwilling to relocate - from having to address the issue.

With increasing firm size the benefits of knowledge externalities are likely to become less and less important. As a range of studies have shown, the geographical distance between partners appears to be of little importance as established companies engage in licensing and other contractual and informal cooperative agreements (Gertler and Levitte, 2003; Gittelman, 2003). Proximity may of course increase the frequency of the kind of unplanned encounters between members of the local epistemic communities that sometimes create opportunities for innovations based on new combinations of ideas (Kreiner and Schultz, 1993). But such ideas are typically rejected by the 'immune systems' of existing firms and such chance events are more likely to favor new firms than the technological development of existing ones.

\section{Cluster Growth and Globalization}

The situation facing firms today is in many ways different from that in Anderstorp during the first half of the last century. Most obviously, the increased efficiency and reduced cost of communication and transportation, in combination with political and economic integration, have made companies dramatically more dependent on foreign influences than before (Dunning, 1993). Foreign influence, of course, whether through trade, immigration, foreign direct investment or through other means, has throughout history been important for the 
economies of the world. However, in the past, such influence was mostly gradual; dramatic upsets were rare and far in-between.

With the advent of 'globalization' the interdependence between firms in different countries and regions has become continuous and immediate. It is all the more fascinating to note that many of the economic processes underlying the dynamics of industrial districts appear to have changed surprisingly little.

A brief comparison of Figure 1 and Figure 3 offers an interesting illustration of this fact. The latter summarizes the genealogy of some of the most important of the so-called "Fairchildren" - the more than 30 firms spawned by Fairchild Semiconductor in Silicon Valley. Fairchild itself had its origin in Shockley Labs, a firm set up by the co-inventor of the transistor to develop the new technology. ${ }^{17}$ The celebrated story of how “The Traitorous Eight”, dismayed with the erratic management style of William Shockley, decided to set up their own company echoes the less illustrious stories retold by William-Olson and Fries (1950) of the founding of new firms in Anderstorp. ${ }^{18}$

\section{INSERT FIGURE 3 ABOUT HERE}

In the mid 1950s, the process vaguely, but commonly, referred to as "globalization" was still in its infancy. However, there is no evidence to suggest that it fundamentally altered the salient mechanisms of cluster growth, as summarized in Figure 2. On the contrary, there are good reasons to believe that "globalization" has served to strengthen the basic processes of agglomeration in evidence long before Marshall’s time (Braudel, 1985).

\section{INSERT FIGURE 4 ABOUT HERE}

Globalization can favor agglomeration and cluster dynamics in three ways (Figure 4): (1) By enlarging the volume of demand that can be addressed from a single location, it can dramatically increase the scope for specialization and division of labor. In some regions, globalization can also (2) increase the volume and importance of inward foreign direct investment, and (3) promote immigration of skilled expertise on an increasingly global scale. Of course, globalization can also pose a threat to previously prosperous regions, whose producers may confront new and potentially overwhelming international competition. How local entrepreneurs 
can successfully react to such threats and in what circumstances 'globalization' favors or undermines the prosperity of existing clusters are important issues, but ones that are too complex to pursue here.

The dominating share of foreign direct investments consists of acquisitions rather than greenfield investments. Foreign acquisitions are undertaken for a range of different strategic motives: access to new markets, production capacity, technology, brand names, etc. In spite of the hype associated with certain 'high-tech' regions, it must not be assumed that FDI there is solely or even primarily motivated by the desire to gain access to the assumed benefits of the locality or the wish to 'tap into' local scientific and technical systems. If a large proportion of an industry's firms is located in a few geographical agglomerations, these regions are likely to be the home of most acquisition targets and will therefore tend to receive a correspondingly high proportion of foreign direct investments. When clusters are said to "attract high volumes of foreign direct investment', the phrase carries connotations that can only sometimes - and far from always - be taken literally.

Whereas the local economic benefits of foreign acquisitions are likely to be modest, the parallel influx of foreign jobseekers and entrepreneurs is potentially much more important (Zander, 2000; Saxenian, 2001). These not only bring partially different knowledge, experience and perspectives in complement of what is already available. ${ }^{19}$ Ethnic and other minorities often display a high level of entrepreneurship. They thereby contribute to the main driving force of cluster dynamics.

\section{Conclusions and Implications for Future Research}

As outlined above, the outstanding features of successful industrial regions are the concentration of specialized and complementary epistemic communities, on the one hand, and a high level of innovation and entrepreneurship, on the other. The two processes are mutually interdependent in ways that are often overlooked.

Much current theorizing on the dynamics of industrial clusters is based on erroneous assumptions regarding the nature and significance of tacit knowledge. It is assumed that firms within clusters have privileged access to 'tacit knowledge' that is unavailable - or available only at high cost - to firms located elsewhere. 
Access to knowledge and specialized expertise is clearly of vital importance. But such knowledge and expertise - regardless of its degree of articulation and codification - can only be accessed and exploited by individuals who are members of relevant epistemic communities. The location of such individuals and the communities to which they belong are the primary determinants of the spatial distribution of knowledge and of the speed of diffusion of new technology.

Moreover, there is a tendency in the literature to use observed characteristics of clusters in the aggregate to make inferences regarding the behavior of its components, i.e. firms, entrepreneurs and the individuals they employ. ${ }^{20}$ As I have argued above, the most fundamental advantages of clusters are due to the simple fact that job seekers and entrepreneurs there can access interesting opportunities without having to incur the costs (in both time and money) of long distance travel or changing their homes and uprooting their families.

For individual firms, locating in a cluster brings both advantages and disadvantages. Whether - or, rather, under what circumstances - the benefits outweigh the corresponding costs is an empirical issue that cannot be resolved by reference to aggregate cluster development. As I have demonstrated above, a high rate of new firm formation and a correspondingly high number of successful new firms can explain the growth and prosperity of clusters. Differences in the rates by which new firms are founded are more important than possible variations in survival rates or the degree to which a cluster location influences subsequent performance.

The conceptual and theoretical problems characteristic of much recent literature on clusters have been aggravated by empirical and methodological ones (Staber, 1996; Malmberg and Maskell, 2002; Martin and Sunley, 2003). As a basis for the formulation and testing of theoretical propositions, the bulk of the many interesting empirical observations available in ethnographic studies of clusters and their dynamics is limited in two related respects.

Although many provide rich and valuable historical background, most are based on crosssectional data and do not capture the failure and exit of cluster firms. The problem of censoring is, of course, generic too much economic research and notoriously difficult to effectively deal with. However, in view of the importance of new firm formation (and death) for 
cluster dynamics, it cannot safely be ignored if we are to arrive at (and test) realistic models of the growth and differentiation of industrial districts.

A second, related problem is that, with important exceptions, most analyses of the operations and activities of firms located in clusters are based on observations sampled on the dependent variable, i.e. cluster membership. Based on the observed behavior of cluster firms, many studies emphasize, for example, the vital importance of close and trustful supplier-buyer relationships, which build on long-standing personal acquaintance (Lissoni, 2001). Apart from the problem of causality - (does successful cooperation emerge out of trustful relations or is it the other way around?) - the proposition that trustful relationships are distinguishing features of firms co-located in specific regions should not be accepted before it has been shown that firms located elsewhere do not maintain similar cooperative arrangements. The same caveat applies to almost all advantages commonly ascribed to cluster membership.

The only empirical strategy that may help us get a better understanding of the processes through which industrial agglomerations emerge and grow is by way of longitudinal studies of cohorts of firms, professionals and entrepreneurs, keeping in mind that the influences that affect the decisions and behaviors of individuals are different from those affecting the fortunes of firms, and that neither can be deduced from observations at the aggregated level of clusters. 


\section{References}

Acs, Z.J., Audretsch, D.B. and Feldman, M.P. (1994), 'R\&D Spillovers and Recipient Firm Size', Review of Economics and Statistics, 76, 336-340.

Almeida, P. and Kogut, B. (1999), 'Localization of Knowledge and the Mobility of Engineers in Regional Networks', Management Science, 45, 905-917.

Almus, M. and Nerlinger, E. A. (1999), 'Growth of New Technology-Based Firms: Which Factors Matter?’, Small Business Economics, 13, 141-154.

Angel, D. (2000), 'High-Technology Agglomeration and the Labor Market: The Case of Silicon Valley’, in M. Kenney (ed.), Understanding Silicon Valley: The Anatomy of an Innovative Region, Stanford University Press: Palo Alto, CA, 124-140.

Antonelli, C. (1994), 'Technology Districts, Localized Spillovers and Productivity Growth: The Italian Evidence on Technological Externalities in Core Regions', International Review of Applied Economics, 8, 18-30.

Appold, S. J. (1995), 'Collaboration and Competition in Geographical Context', Economic Geography, 71, 27-54.

Asheim, B.T. (1996), 'Industrial Districts and 'Learning Regions': A Condition for Prosperity’, European Planning Studies, 4, 379-401.

Audretsch, D.B. (1998), 'Agglomeration and the Location of Innovative Activity', Oxford Review of Economic Policy, 14, 18-29.

Audretsch, D.B. and Feldman, M.P. (1996), 'R\&D Spillovers and the Geography of Innovation and Production’, American Economic Review, 86, 630-640.

Baptista, R. and Swann, P. (1998), 'Do Firms in Clusters Innovate More?', Research Policy, 27, 525-540.

Bathelt, H, Malmberg, A. and Maskell, P. (2002), 'Cluster and Knowledge: Local Buzz, Global Pipelines and the Process of Knowledge Creation', Danish Research Unit for Industrial Dynamics, DRUID Working Paper No. 02-12.

Beal, B. D. and Gimeno, J. (2001), 'Geographic Agglomeration, Knowl3edge Spillovers, and Competitive Evolution’, INSEAD Working Paper No. 2001/26/SM.

Beaudry, C. (2001), 'Entry, Growth and Patenting in Industrial Clusters: A Study of the Aerospace Industry in the UK', International Journal of the Economics of Business, 8, 405-436.

Beaudry, C., Breschi, S. and Swann, P. (2002), 'Clusters, Innovation and Growth. A Comparative Study if European Countries', in J. H. Dunning and J.-L. Mucchielli (eds.), Multinational Firms: The Global-Local Dilemma. Routledge: London, 190-213.

Becatttini, G., Bellandi, M., Dei Ottati, G. and Sforzi, F. (2003), From Industrial Districts to Local Development. An Itinerary of Research. Edward Elgar: Cheltenham.

Benito, R.G., Grøgaard, B. and Narula, R. (2003), 'Environmental Influences on MNE Subsidiary Roles: Economic Integration and the Nordic Countries', Journal aof International Business Studies, 34, 443-456. 
Boden, R.J,. Jr. (2000), 'Establishment Employment Change and Survival, 1992-1996. Final Report Prepared for the Office of Advocacy of the U.S. Small Business Administration.' (http://www.sba.gov/advo/research/rs200tot.pdf),

Braudel. F. (1985), The Wheels of Commerce: Civilization and Capitalism, 15th-18th Century, Volume 2. HarperCollins: London.

Breschi, S. and Lissoni, F. (2001a), 'Knowledge Spillovers and Local Innovation Systems: A Critical Survey’, Industrial and Corporate Change, 10, 975-1005.

Breschi, S. and Lissoni, F. (2001b), 'Localised Knowledge Spillovers vs. Innovative Milieux: Knowledge “Tacitness” Reconsidered”, Papers in Regional Science, 80, 255-273.

Brown, J. S. and Duguid, P. (2000), 'Mysteries of the Region: Knowledge Dynamics in Silicon Valley', in C.-M. Lee, W. F. Miller, M. G. Hancock and H. S. Rowen (eds.), The Silicon Valley Edge: A Habitat for Innovation and Entrepreneurship. Stanford University Press: Palo Alto, CA, 16-39.

Brown, J. S. and Duguid, P. (2001), 'Knowledge and Organization: A Social-Practice Perspective’, Organization Science, 12, 198-213.

Camagni, R. (1991), 'Local 'Milieu', Uncertainty and Innovation Networks: Toward a New Dynamic Theory of Economic Space', in R. Camagni (ed.), Innovation Networks: Spatial Perspectives, Belhaven: London, 121-142.

Cowan, R., David, P.A. and Foray, D. (2000), 'The Explicit Economics of Knowledge Codification and Tacitness', Industrial and Corporate Change, 9, 211-253.

Dahl, M.S., Dalum, B. and Pedersen, C. Ø. R. (2003), 'New Firm Formations and Inherited Organizational Capabilities: Analyzing Modes of Entry in a High-Tech Cluster', Paper presented at the DRUID summer conference, Copenhagen, June 12-13, 2003.

Dahmén, E. (1988), “'Development Blocks’ in Industrial Economics', Scandinavian Economic History Review, 3, 3-14.

Dosi, G. (1988), 'Sources, Procedures, and Microeconomic Effects of Innovation', Journal of Economic Literature, 26, 1120-71.

Dunning, J. (1993), 'Internationalizing Porter's Diamond', Management International Review, 33, 7-15.

Eisenhardt, K. M. and Schoonhoven, C. B. (1990), 'Organizational Growth: Linking Founding Team, Strategy, Environment and Growth Among U. S. Semiconductor Ventures (1978-1988)', Administrative Science Quarterly, 35, 504-529.

Eisenhardt, K. M. and Santos, F. M. (2002), 'Knowledge-Based View: A New Theory of Strategy?' in A. Pettigrew, H. Thomas and R. Whittington, (eds.), Handbook of Strategy and Management, Sage: London, 139-164.

Feldman, M. P. (1999), 'The New Economics of Innovation, Spillovers and Agglomeration: A Review of Empirical Studies', Economics of Innovation and New Technology, 8, 525.

Feldman, M. P. (2000a), 'Where Science Comes to Life: University Bioscience, Commercial Spin-offs, and Regional Economic Development', Journal of Comparative Policy Analysis: Research and Practice, 2, 345-361.

Feldman, M. P. (2000b), 'Location and Innovation: The New Economic Geography of Innovation, Spillovers, and Agglomeration', in G. L. Clark, M. A. Feldman and M. S. 
Gertler (eds.), The Oxford Handbook of Economic Geography. Oxford University Press: Oxford, 373-394.

Feldman, M. P. and Florida, R. (1994), 'The Geographic Sources of Innovation: Technological Infrastructure and Product Innovation in the United States', Annals of the Association of American Geographers, 84, 210-229.

Foray, D. (1991), 'The Secrets of Industry are in the Air: Industrial Cooperation and the Organizational Dynamics of the Innovative Firm', Research Policy, 20, 393-405.

Garvin, D. A. (1983), 'Spin-Offs and the New Firm Formation Process', California Management Review, 25, 3-20.

Gertler, M. (1995), “'Being There’: Proximity, Organization, and Culture in the Development and Adoption of Advanced Manufacturing Technologies’, Economic Geography, 71, $1-26$.

Gertler, M. (2003), 'Tacit Knowledge and the Economic Geography of Context, or The Undefinable Tacitness of Being (There)', Journal of Economic Geography, 3, 75-99.

Gertler, M. S. and Levitte, Y. (2003), 'Local Nodes in Global Networks: The Geography if of Knowledge Flows in Biotechnology Innovation.' Paper presented at the DRUID Summer Conference, Copenhagen, June 12-13, 2003.

Gittelman, M. (2003), 'Does Geography Matter for Science-Based Firms? Epistemic Communities and the Geography of Research and Patenting in Biotechnology', Department of Management and Organizational Behavior, NYU Stern School of Business. (Mimeo.)

Glaeser, E. L., Kallal, H. D., Scheinkman, J. A. and Schleifer, A. (1992), 'Growth in Cities', Journal of Political Economy, 100, 1126-1152.

Goodman, E. and Bamford, J. (eds.) (1989), Small Firms and Industrial Districts in Italy. Routledge: London.

Grabher, G. (1993), 'Rediscovering the Social in the Economics of Interfirm Relations', in G. Grabher (ed.), The Embedded Firm: On the Socioeconomics of Industrial Networks. Routledge: London.

Haas, P.M. (1992), 'Introduction: Epistemic Communities and International Policy Coordination’, International Organization, 46, 1-37.

Håkanson, L. (2003), 'Creating Knowledge - The Power and Logic of Articulation', Competitive paper for the 2003 Academy of Management Conference, Seattle, August 3-6, 2003.

Hamilton, F. E. I. and Linge, G. J. R. (eds.) (1979), Spatial Analysis, Industry and the Industrial Environment, Volume 1: Industrial Systems. Wiley: Chichester.

Hamilton, F. E. I. and Linge, G. J. R. (eds.) (1981), Spatial Analysis, Industry and the Industrial Environment, Volume 2: International Industrial Systems. Wiley: Chichester.

Hamilton, J., \& Himelstein, L. (1997), ’A Wellspring Called Stanford', Business Week, August 25, 62-64.

Hanson, G. (2000), 'Firms, Workers, and the Geographic Concentration of Economic Activity', in G. L. Clark, M. Feldman and M. Gertler (eds.), Oxford Handbook of Economic Geography. Oxford University Press: Oxford, 477-494. 
Harrison, B. , Kelley, M. and Gant, J. (1996), 'Innovative Firm Behavior and Local Milieu: Exploring the Intersection of Agglomeration, Firm Effects, and Technological Change’, Economic Geography, Vol. 72, pp. 233-258.

Hedlund, G. and Zander, U. (1993), 'Architectonic and List-Like Knowledge Structuring: A Critique of Modern Concepts of Knowledge Management', Research Paper 1993/2. Institute of International Business, Stockholm School of Economics.

Helfat, C.E. and Lieberman, M. B. (2002), 'The Birth of Capabilities: Market Entry and the Importance of Pre-history’, Industrial and Corporate Change, 11, 725-760.

Hendry, C. and Brown, J. (1998), Clustering and Performance in the UK Opto-Electronics Industry: Regional Advantage and Innovation. Universidade Catolica Portugese: Porto.

Isard, W. and Schooler, E. W. (1959), 'Industrial Complex Analysis, Agglomeration Economics and Regional Development', Journal of Regional Science, 1,

Jaffe, A., Trajtenberg, M. and Henderson, R. (1993), 'Geographic Localization of Knowledge Spillovers’, Quarterly Journal of Economics, 108, 577-598.

Jones, C., Hesterly, W. S., \& Borgatti, S. P. (1997), 'A General Theory of Network Governance: Exchange Conditions and Social Mechanisms', Academy of Management Review, 22, 911-945.

Keeble, D. and Wilkinson, F. (1999), 'Collective Learning and Knowledge Development in the Evolution of Regional Clusters of High Technology SMEs in Europe', Regional Studies, 33, 295-303.

Keeble, D., Lawson, C., Moore, B. and Wilkinson, F. (1999), 'Collective Learning Processes, Networking and 'Institutional Thickness' in the Cambridge Region', Regional Studies, 33, 319-332.

Kenney, M. and von Burg, U. (1999), 'Technology, Entrepreneurship and Path Dependence: Industrial Clustering in Silicon Valley and Route 128', Industrial and Corporate Change, 8, 67-103.

Kirchhoff, B. A. (1994a), Entrepreneurship and Dynamic Capitalism. Praeger: Westport, CT.

Kirchhoff, B. A. (1994b), 'Entrepreneurship Economics', in W. D. Bygrave (ed.), The Portable Guide in Entrepreneurship. Wiley: New York, 410-439.

Klepper, S. (2001), 'Employee Startups in High-Tech Industries', Industrial and Corporate Change, 10, 639-674.

Kreiner, K. and Schultz, M. (1993), 'Informal Collaboration in R\&D. The Formation of Networks Across Organizations’, Organization Studies, 14, 189-209.

Krugman, P. (1991), Geography and Trade. MIT Press: Cambridge, MA.

Lave, J. and Wenger, E. (1991), Situated Learning: Legitimate Peripheral Participation. Cambridge University Press: New York.

Lawson, C. (1999), 'Towards a Competence Theory of the Region', Cambridge Journal of Economics, 23, 151-166.

Lawson, C. and Lorenz, E. (1999), 'Collective Learning, Tacit Knowledge and Regional Innovative Capacity’, Regional Studies, 33, 305-317. 
Lissoni, F. (2001), 'Knowledge Codification and the Geography of Innovation: The Case of Brescia Mechanical Cluster', Research Policy, 30, 1479-1500.

Loasby, B.J. (1998), 'Industrial Districts as Knowledge Communities', in M. Bellet and C. L'Harmet (eds.), Industry, Space and Competition: The Contribution of the Economists of the Past. Edward Elgar: Cheltenham.

Malmberg, A. and Maskell, P. (1997), 'Toward an Explanation of Regional Specialization and Industry Agglomeration’, European Planning Studies, 5, 25-41.

Malmberg, A. and Maskell, P. (2002), 'The Elusive Concept of Localization Economies: Towards a Knowledge-Based Theory of Spatial Clustering', Environment and Planning A, 34, 429-449.

Markusen, A. (1996), 'Sticky Places in Slippery Space’, Economic Geography, 72, 293-313.

Markusen, A. (1999), 'Fuzzy Concepts, Scanty Evidence, Policy Distance: The Case for Rigour and Policy Relevance in Critical Regional Studies’, Regional Studies, 33, 869884.

Marshall, A. (1920), Principles of Economics. $8^{\text {th }}$ edition. Macmillan: London.

Martin, R. (1999), 'The New 'Geographical Turn’ in Economics: Some Critical Reflections', Cambridge Journal of Economics, 23, 65-91.

Martin, R. and Sunley, P. (2003), 'Deconstructing Clusters: Chaotic Concept of Policy Panacea', Journal of Economic Geography, 3, 5-35.

Maskell, P, and Malmberg, A. (1999a), 'Localised Learning and Industrial Competitiveness', Cambridge Journal of Economics, 23, 167-185.

Maskell, P, and Malmberg, A. (1999b), 'The Competitiveness of Firms and Regions. 'Ubiquitification' and the Importance of Localized Learning', European Urban and Regional Studies, 6, 9-25.

Maskell, P. (2001), 'Towards a Knowledge-based Theory of the Geographical Cluster', Industrial and Corporate Change, 10, 921-943.

McEvily, S. K. and Chakravathy, B. (2002), 'The Persistence of Knowledge-Based Advantage: An Empirical Test for Product Performance and Technological Knowledge', Strategic Management Journal, 23, 285-305.

Morgan, K. (1997), 'The Learning Region: Institutions, Innovation and Regional Renewal', Regional Studies, 31, 491-503.

Mudambi, R. and Treichel, M. Z. (2003) 'Cash Crises in Newly Public Internet-Based Firms: An Empirical Analysis. Innovation and Entrepreneurship Institute Discussion Paper 3/03, Fox School of Business, Temple University.

Murtha, T. P., Lenway, S. A., and Hart, J. A. (2001), Managing New Industry Formation: Global Knowledge Formation and Entrepreneurship in High Technology. Stanford University Press: Stanford, CA.

Narula, R. (2003) Globalization \& Technology. Cambridge: Polity Press.

Perroux, F. (1988), 'The Pole of Development's New Place in a General Theory of Economic Activity', in B. Higgins and D.J. Savoi (eds.), Regional Economic Development. Essays in Honour of François Perroux. Unwin Hyman: Boston. 
Philips, B.D. and Kirchhoff, B.A. (1989), 'Formation, Growth and Survival: Small Firm Dynamics in the U.S. Economy', Small Business Economics, 1, 65-74.

Piori, M. and Sabel, C. (1984), The Second Industrial Divide: Possibilities for Prosperity. Basic Books: New York.

Polanyi, M. (1962), Personal Knowledge: Towards a Post-Critical Philosophy. Harper \& Row: New York.

Polanyi, M. (1966), The Tacit Dimension. Doubleday: Garden City, NY.

Popkin, Joel and Company (1991), 'Business Survival Rates by Age Cohort of Business. Report Prepared for the Office of Advocacy of the U.S. Small Business Administration.' (http://www.sba.gov/advo/research/rs122.html),

Porter, M.E. (1998), 'Clusters and the New Economics of Competition', Harvard Business Review, 76, Nov./Dec., 77-90.

Pouder, R. and St. John, C. (1996), 'Hot Spots and Blind Spots: Geographical Clusters of Firms and Innovation', Academy of Management Review, 21, 1192-1225.

Pyke, F. and Sengenberger, W. (eds.) (1990), Industrial Districts and Inter-firm Co-operation in Italy. ILO: Geneva.

Romanelli, E, and Schoonhoven, C. B. (2001), 'The Local Origins of New Firms', in C. B. Schoonhoven and E. Romanelli (eds.), The Entrepreneurship Dynamic: Origins of Entrepreneurship and the Evolution of Industries. Stanford University Press: Stanford, CA.

Russo, M. (1996), 'Units of Investigation for Local Economic Development Policies', Materiali di dicussione, No. 106, Dipartimento di Economia Politica, Università degli studi di Modena.

Saxenian, A. (1994), Regional Advantage: Culture and Competition in Silicon Valley and Route 128. Harvard University Press: Cambridge, MA.

Saxenian, A. (2001), 'The Role of Immigrant Entrepreneurs in New Venture Creation', in C. B. Schoonhoven and E. Romanelli (eds.), The Entrepreneurship Dynamic: Origins of Entrepreneurship and the Evolution of Industries. Stanford University Press: Stanford, CA, 68-108.

Schoonhoven, C. B. and Eisenhardt, K. M. (1992), 'Regions as Industrial Incubators of Technology-based Ventures', in E. S. Mills and J. F. McDonald (eds.), Sources of Metropolitan Growth. Center for Urban Policy Research: New Brunswick, NJ, 210-252.

Smith, D.M. (1971), Industrial Location. An Economic Geographical Analysis. New York.

Spender, J.-C. 1989. Industry Recipes. Basil Blackwell: Oxford.

Staber, U. (1996), 'Accounting for Variations in the Performance of Industrial Districts: The Case of Baden-Würtemberg', International Journal of Urban and Regional Research, 20, 299-316.

Staber, U. (1998), 'Inter-firm Co-operation and Competition in Industrial Districts', Organization Studies, 19, 701-724.

Storper, M. (1992), 'The Limits to Globalization: Technology Districts and International Trade’, Economic Geography, 68, 60-93. 
Storper, M. and Harrison, B. (1991), 'Flexibility, Hierarchy and Regional Development: The Changing Structure of Industrial Production Systems and Their Forms of Governance in the 1990s', Regional Policy, 20, 407-422.

Sturgeon, T. J. (2000), 'How Silicon Valley Came to Be', in M. Kenney (ed.), Understanding Silicon Valley: The Anatomy of an Innovative Region. Stanford University Press: Palo Alto, 15-47.

Von Hippel, E. (1994), 'Sticky Information' and the Locus of Problem Solving: Implications for Innovation’, Management Science, 40, 429-39.

William-Olsson, W. and Fries, P. (1950), Halmstad Nässjö järnvägar och näringslivet i deras trafikområde. HNJ Järnvägar: Halmstad.

Zander, U. (2000), 'When Muhammed Goes to the Mountain: Globalization, Cathedrals of Modernity, and a New World in Order', Academy of Management Proceedings 2000.

Zander, U. 1991. Exploiting a Technological Edge - Voluntary and Involuntary Dissemination of Technology. Institute of International Business: Stockholm.

Zander, U. and Kogut, B. (1995), 'Knowledge and the Speed of Transfer and Imitation of Organizational Capabilities: An Empirical Test’, Organization Science, 6, 76-92.

Zollo, M. and Winter, S. G. (2002), 'Deliberate Learning and the Evolution of Dynamic Capabilities’, Organization Science, 13, 339-351.

Zucker, L.G., Darby, M.R. and Armstrong, J. (1998), 'Geographically Localized Knowledge: Spillovers or Markets?’ Economic Inquiry, 36, 65-86. 


\section{Endnotes}

${ }^{1}$ The supporting institutional, social and cultural elements of, say, Italian industrial districts are notably different from those of Silicon Valley or southern California but the pattern of personnel exchange, cooperation, risk and knowledge sharing appears to be sufficiently similar to view them as members of the same theoretical category (Goodman and Bamford, 1989; Pyke and Sengenberger, 1990).

${ }^{2}$ It is difficult to disagree with the sentiment expressed by Brown and Duguid (2000, p. 16) that by and large we are only "adding footnotes" to Marshall's original exposition. Then again, many of the ideas informing Marshall's understanding of industrial districts can be traced even further back to Adam Smith (Loasby 1988).

${ }^{3}$ Staber (1996, 1998), Berschi and Lissoni (2001a, 2001b) and Gertler (2003) offer interesting exceptions.

${ }^{4}$ Following Polanyi (1966), some writers like to emphasize that the two types of knowledge are complementary and that you cannot have the one without the other; others prefer to see them as the two ends of a continuum. However, these seemingly sophisticated nuances to the argument do not alter its fundamental structure (which remains flawed).

${ }^{5}$ As Gertler (2003, p. 77) correctly notes, “....the general tendency to conflate 'uncodified' with 'uncodifiable' has led to some conceptual sloppiness within the economic geography on local innovation dynamics.” And not only there, one might add (see, e. g, Eisenhardt and Santos, 2002, p. 160).

${ }^{6}$ As Hedlund and Zander (1993, p. 12) perceptively note, “'tacit knowledge'... is posed as that which is not articulated, articulable, codified or codifiable. As in all cases of negative definitions, the risk is that a heterogeneous assemblage of aspects is subsumed under one label. One gets the distinct feeling that authors take refuge in tacitness largely because they have encountered something they do not understand."

${ }^{7}$ Introducing yet another misleading metaphor, the idea has recently been advanced that through the establishment of 'global pipelines' it may be possible to convey tacit knowledge through other means than face-to-face contact (Bathelt et al., 2002). Precisely what sort of mechanisms are at work in such 'pipelines' remains obscure.

${ }^{8}$ In a parallel line of argument, Brown and Duguid (2000; 2001) propose the term 'networks of practice.' This term has the advantage of drawing attention to the instrumental aspects of knowledge: 'networks of practice', like 'communities of practice' develop over time in the common pursuit of a shared enterprise; they exist because they have a task to accomplish. Although originally proposed in a different context and with slightly different connotations (Haas, 1992), I shall prefer the term 'epistemic communities' because it implies no assumption as to the frequency of contact between members.

${ }^{9}$ As noted already in Allen's (1977) classic study of the communication patterns in R\&D laboratories, idiosyncratic coding schemes enhance communication among local community members but often impede communication with 'outsiders': "There is a great deal of overlap among the coding schemes of different organizations operating within the same culture. On the other hand, the nonoverlapping areas, however small, can potentially operate to produce semantic noise, and they can be even more troublesome because it can go undetected" (Allen 1977, p. 139).

${ }^{10}$ In this sense, the art of a make-up artist is complementary to, but quite distinct from, that of an actress, as is the practice of patent lawyers to that of venture capitalists. In contrast, the knowledge and skills of scriptwriters 
for television commercials are related to, and partially overlap with, those of playwrights. These types of relationships between individual groups of professionals and the types of practice that their members pursue are unaffected by whether the corresponding activities are organized as independent firms or within larger legal entities. An implication of the argument outlined in this paper is that a better understanding of cluster dynamics requires a better microeconomic understanding of individual behavior - how do people decide where and how (as independent entrepreneurs or as employees) to exploit their skills?

${ }^{11}$ As Porter (1998, p. 77) points out in the case of the Massachusetts medical devices cluster, the practice in question needs not match standard industrial classification systems.

${ }^{12}$ In Småland of the early $20^{\text {th }}$ century, the dream of fairy-tale wealth and early retirement was probably not a major driving force. The goals of the small-scale entrepreneurs that William-Olson interviewed were more mundane; escape from a quarrelsome boss and the desire for some independence stand out as prominent motives.

${ }^{13}$ A caveat to this proposition should be noted: The successful growth of existing firms may offer career opportunities that reduce the perceived relative attractiveness of risky entrepreneurial ventures.

${ }^{14}$ The table is not exhaustive but does include all studies that I have been able to identify that provide empirical firm level results regarding the effect of localization and urbanization economies. The strong negative relationship between cash flow and a location in Silicon Valley and New York reported by Mudambi and Zimmerman (2003) was incidental to the main purpose of their study. The location dummies were included as controls with the expectation that they would positively impact firm performance. Benito et al. (2003) also used cluster location as a control variable but found it to have no significant effect.

${ }^{15}$ As one expert on the topic puts it in a popular textbook: "Location is not an impediment to entrepreneurial success. You can start your firm in any location regardless of tax rates, living conditions or other touted advantages... If you like where you live, stay there. Do not let someone convince you to move to start your business” (Kirchhhoff, 1994b, p. 437).

${ }^{16}$ Kenney and van Burg (1999, p. 75) quotes an article in the Wall Street Journal, featuring a consultant whose sole activity was to aid business people prepare their presentations to stock analysts on the launch of IPOs.

${ }^{17}$ Many accounts of Silicon Valley's history start with the 1955 founding of Shockley Labs, others go back to the formation of Hewlett Packard in 1938. However, as Sturgeon (2000) has shown, the structures of industrial organization and cluster dynamics originated much earlier: "A leading role for local venture capital; a close relationship between local industry and the major research universities of the area; a product mix with a focus on electronic components, production equipment, advanced communications, instrumentation, and military electronics; an unusually high level of interfirm cooperation; a tolerance for spinoffs... were as much in evidence from 1910 through 1940 as they have been from the 1960s onward” (Sturgeon, 2000, pp. 16 f.).

${ }^{18}$ Kenney and von Burg (1999) provide similar genealogies of firms in the disk drive and LAN industries, Dahl et al. (2003) for the wireless communications cluster in North Denmark.

${ }^{19}$ Already Marshall (1920, p. 198) emphasized the role of immigration for cluster development: "[T] part of England's manufacturing industry before the era of cotton and steam had its course directed by settlements of Flemish and other artisans: ... These immigrants taught us to weave woolen and worsted stuffs, though 
for a long time we sent our cloths to the Netherlands to be fulled and dyed. They taught us how to cure herrings, how to manufacture silk, how to make lace, glass, and paper...”

20 "The externalities that contribute to spatial agglomeration, such as spillovers between workers, learning across firms or cost and demand linkages between local industries, are difficult to observe. We are left to infer their existence from the covariance if observed variables such as wages, employment and output” (Hanson, 2000, p. 481). 


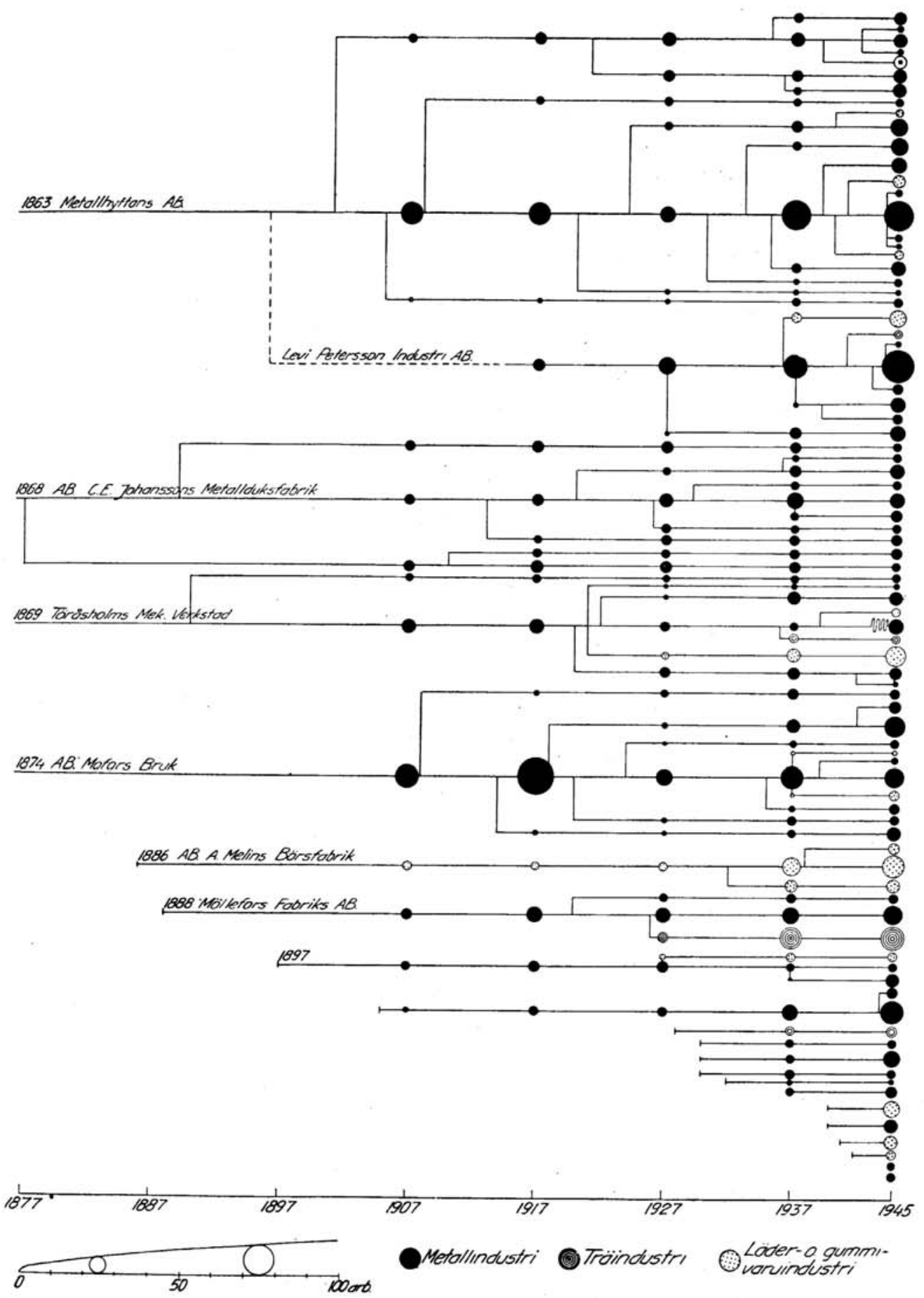

Fig. 52. Industriernas uppkomst och utveckling i Anderstorp.

Figure 1. The Growth and Development of Industries in Anderstorp 1877-1945 (William-Olson and Fries, 1950). 


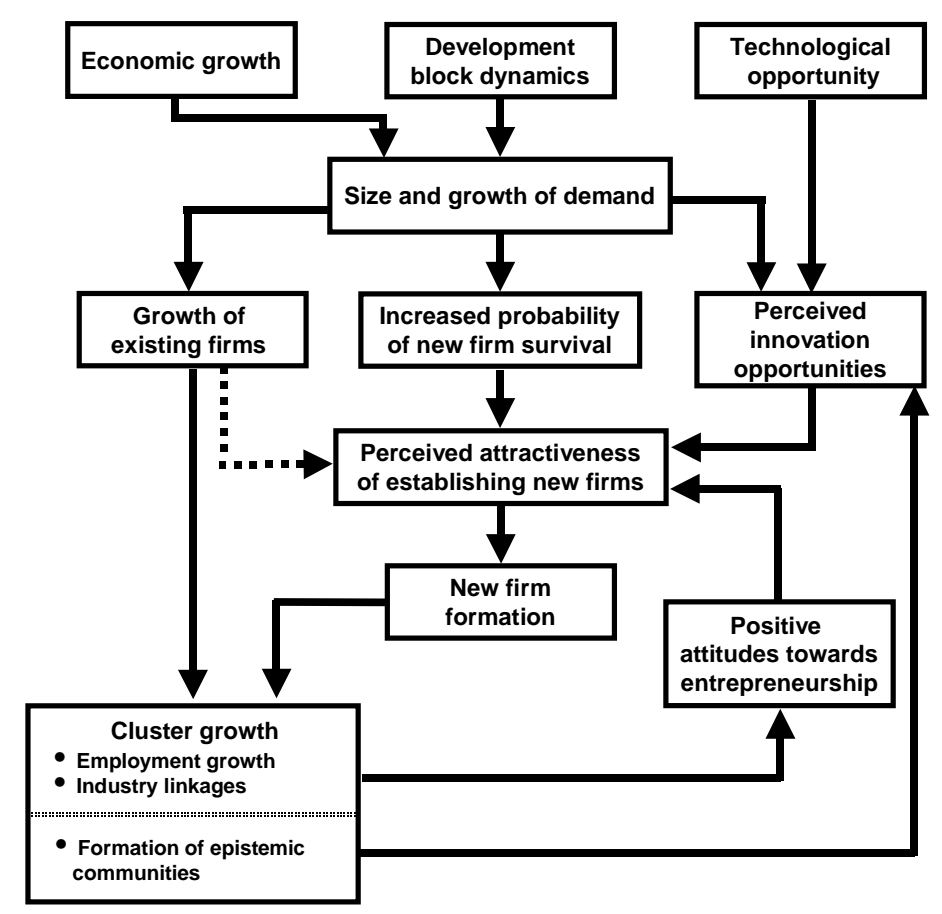

Figure 2. A Model of Cluster Dynamics in a Closed Economy

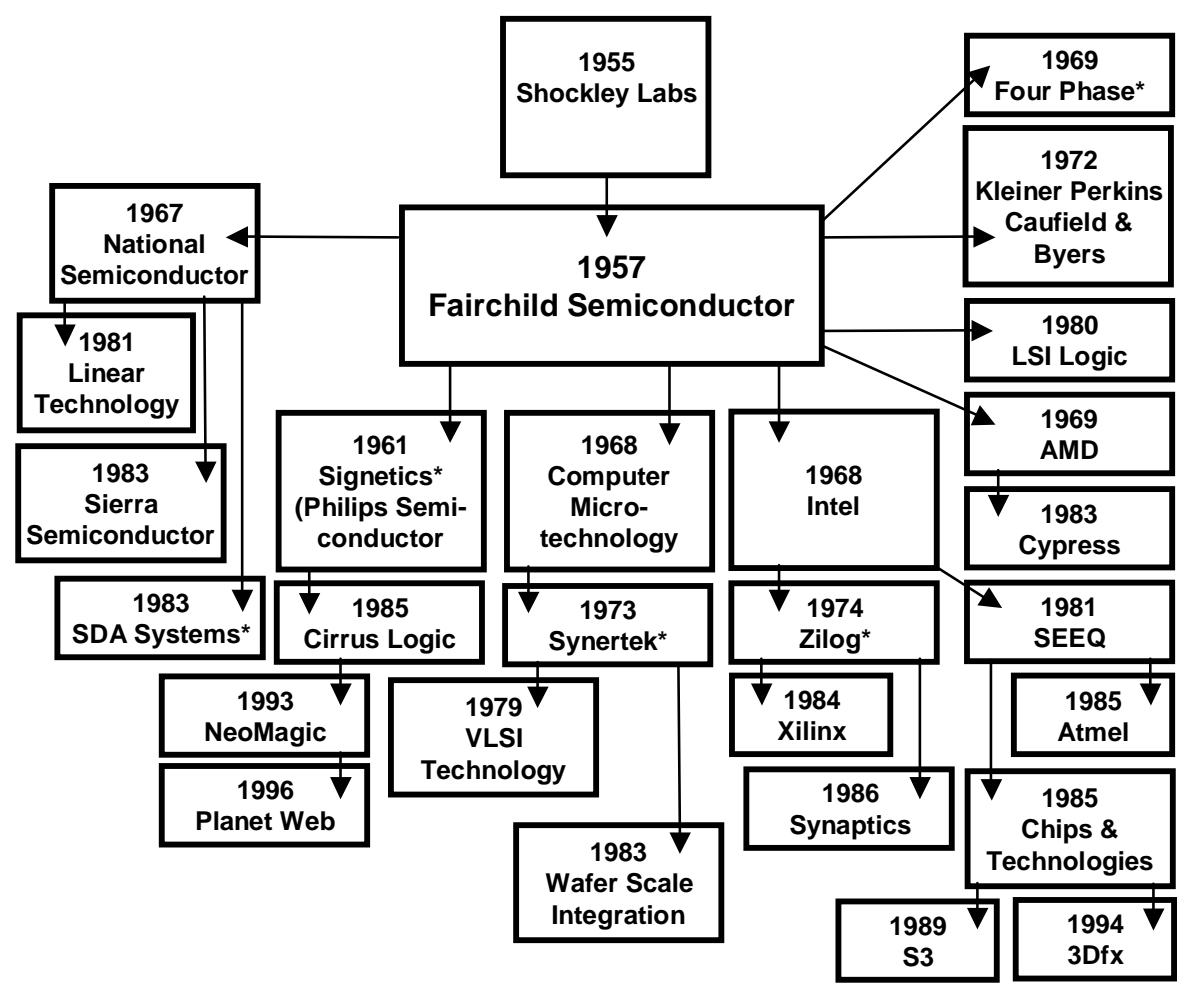

Figure 3. The "Fairchildren” (Adapted from Hamilton \& Himelstein, 1997) 


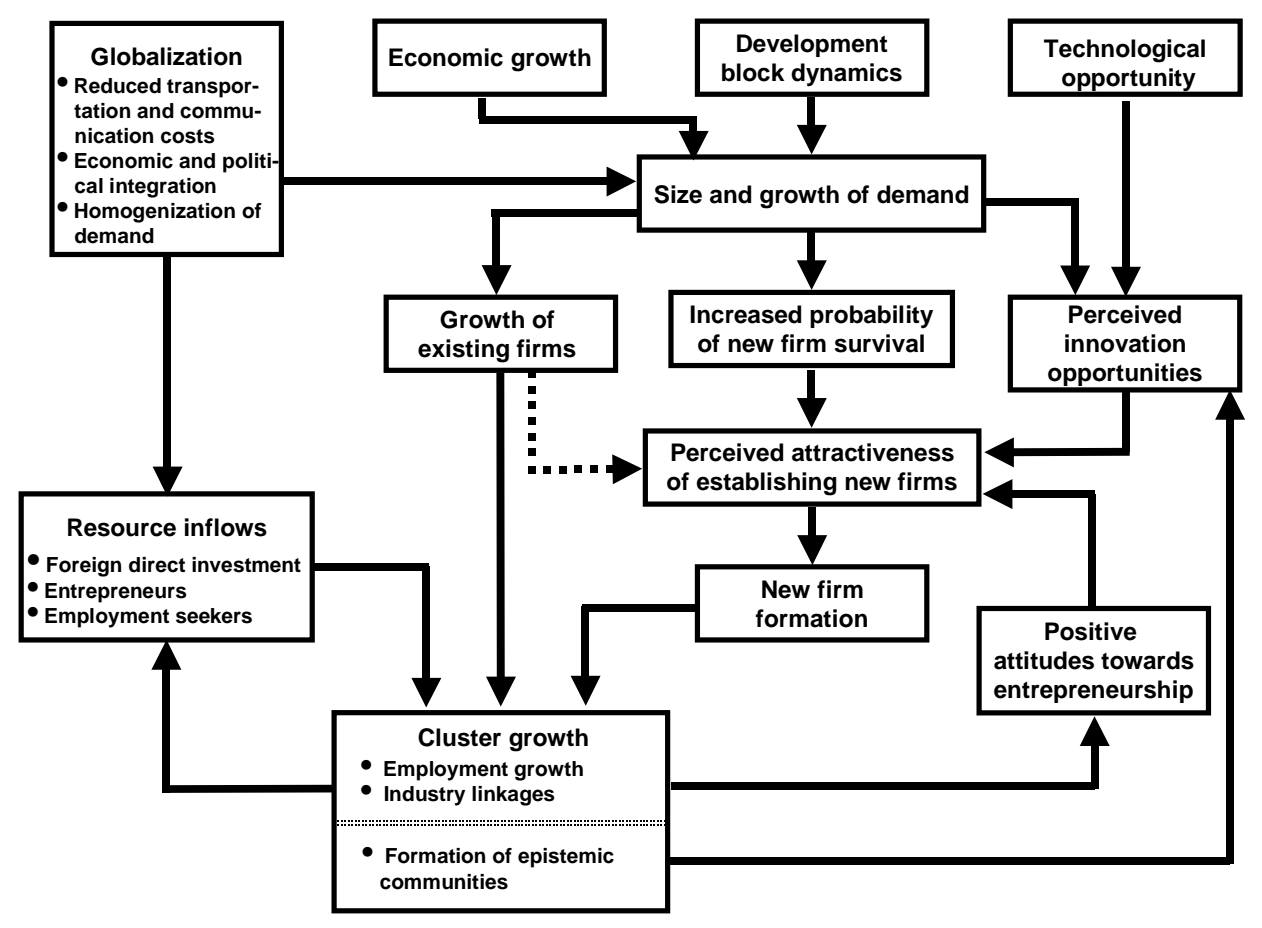

Figure 4. A Model of Cluster Dynamics in an Open Economy 


\begin{tabular}{|c|c|c|c|}
\hline Source & Sample/Context & Effect of cluster/agglomeration location & $\begin{array}{l}\text { Effect on } \\
\text { Performance* }\end{array}$ \\
\hline $\begin{array}{l}\text { Almus and Nerlinger } \\
\text { (1999) }\end{array}$ & $\begin{array}{l}\text { 32,045 German firms } \\
\text { (2,679 high tech firms) } \\
\text { 1989-1998 }\end{array}$ & $\begin{array}{l}\text { Average annual growth rates negatively correlated } \\
\text { with county population densities. (No significant } \\
\text { relationship in high tech industries.) }\end{array}$ & $\mathrm{U}:-$ \\
\hline Antonelli (1994) & $\begin{array}{l}92 \text { large Italian firms in } \\
\text { nine core regions }\end{array}$ & $\begin{array}{l}\text { Interaction between firms' own R\&D and R\&D } \\
\text { intensity of other local firms positively related to } \\
\text { productivity growth. }\end{array}$ & $\mathrm{U}:+$ \\
\hline Appold (1995) & $\begin{array}{l}973 \text { U.S. metal working } \\
\text { firms 1986/87 and } 1991\end{array}$ & $\begin{array}{l}\text { Establishments' competitiveness, measured by } \\
\text { distance to principal customer, negatively related to } \\
\text { size of local cluster. }\end{array}$ & $\mathrm{L}:-$ \\
\hline $\begin{array}{l}\text { Baptista and Swann } \\
\text { (1998) }\end{array}$ & $\begin{array}{l}\text { Innovations by } 248 \\
\text { U.K. companies } 1975- \\
82 \text {. }\end{array}$ & $\begin{array}{l}\text { Location in same-industry clusters increases } \\
\text { probability of innovation. Local employment in other } \\
\text { industries has no significant effect. }\end{array}$ & $\begin{array}{l}\mathrm{L}:+ \\
\mathrm{U}: 0\end{array}$ \\
\hline $\begin{array}{l}\text { Beal and Gimeno } \\
\text { (2001) }\end{array}$ & $\begin{array}{l}56 \text { U.S. PC software } \\
\text { firms } 1982-1998\end{array}$ & $\begin{array}{l}\text { Clustering negatively related to R\&D intensity, } \\
\text { unrelated to innovative output (new products) and } \\
\text { performance. }\end{array}$ & $\mathrm{L}: 0$ \\
\hline Beaudry (2001) & $\begin{array}{l}548 \text { UK firms in the } \\
\text { aerospace industry } \\
1988-1994\end{array}$ & $\begin{array}{l}\text { In some (but not all) sectors of the industry, location in } \\
\text { same-sector cluster positively affects growth rates and } \\
\text { patenting. }\end{array}$ & L: Mixed \\
\hline $\begin{array}{l}\text { Beaudry, et al. } \\
\text { (2002) }\end{array}$ & $\begin{array}{l}\text { Firm employment in } \\
\text { two-digit industries in } 7 \\
\text { European countries } \\
\text { early 1990s }\end{array}$ & $\begin{array}{l}\text { Location in same-industry clusters negatively related } \\
\text { to firm growth in } 4 \text { of seven countries, unrelated in the } \\
\text { rest. Large variation in effects between industries. }\end{array}$ & $\begin{array}{l}\mathrm{L}: \text { Mixed } \\
\mathrm{U}: \text { Mixed }\end{array}$ \\
\hline Benito, et al. (2003) & $\begin{array}{l}\text { Scope of activities and } \\
\text { level of competence in } \\
728 \text { foreign-owned } \\
\text { subsidiaries in } \\
\text { Denmark, Finland and } \\
\text { Norway. }\end{array}$ & $\begin{array}{l}\text { Location in a local national cluster not significantly } \\
\text { related to scope of activities and level of competence } \\
\text { of foreign subsidiaries. }\end{array}$ & $\mathrm{L}: 0$ \\
\hline Boden (2000) & $\begin{array}{l}\text { Survival among } \\
\text { 178,736 independent } \\
\text { non-farm U.S. business } \\
\text { establishments 1992- } \\
1996\end{array}$ & $\begin{array}{l}\text { Median survival rates for firms located in Standard } \\
\text { Metropolitan Areas significantly lower than for those } \\
\text { located elsewhere. }\end{array}$ & $\mathrm{U}:-$ \\
\hline Glaeser, et al. (1992) & $\begin{array}{l}\text { Change in industry } \\
\text { employment in } 170 \\
\text { large U.S. cities } 1956 \\
\text { to } 1987\end{array}$ & $\begin{array}{l}\text { Industries grow significantly slower in cities where } \\
\text { they are over-represented. Industries grow } \\
\text { significantly faster in less specialized cities. }\end{array}$ & $\begin{array}{l}\mathrm{L}:- \\
\mathrm{U}:+\end{array}$ \\
\hline $\begin{array}{l}\text { Harrison, et al. } \\
\text { (1996) }\end{array}$ & $\begin{array}{l}\text { Adoption of program- } \\
\text { mable automation tech- } \\
\text { nology in } 962 \text { U. S. } \\
\text { metal-working estab- } \\
\text { lishments 1982-1987. }\end{array}$ & $\begin{array}{l}\text { Probability of adopting new technology positively } \\
\text { related to proximity to urban centers but unrelated to } \\
\text { regional sectoral specialization. }\end{array}$ & $\begin{array}{l}\mathrm{L}: 0 \\
\mathrm{U}:+\end{array}$ \\
\hline $\begin{array}{l}\text { Kukalis and Stanton } \\
\text { (2003) }\end{array}$ & $\begin{array}{l}\text { U.S. semiconductor } \\
\text { firms }\end{array}$ & $\begin{array}{l}\text { Cluster location has no significant effect on per- } \\
\text { formance }\end{array}$ & $\mathrm{L}: 0$ \\
\hline $\begin{array}{l}\text { Mudambi and Zim- } \\
\text { merman (2003) }\end{array}$ & $\begin{array}{l}158 \text { U.S. Internet-based } \\
\text { IPO’s 1997-1999 }\end{array}$ & $\begin{array}{l}\text { Location in Silicon Valley or NYC has significantly } \\
\text { negative influence on cash position. }\end{array}$ & $\mathrm{L}:-$ \\
\hline $\begin{array}{l}\text { Popkin and Co. } \\
\text { (1991) }\end{array}$ & $\begin{array}{l}\text { Survival among }>4 \\
\text { million US companies } \\
1976-1986\end{array}$ & Survival rates do not vary with geographical location. & $\mathrm{U}: 0$ \\
\hline $\begin{array}{l}\text { Schoonhoven and } \\
\text { Eisenhardt (1992) }\end{array}$ & $\begin{array}{l}102 \text { U. S. } \\
\text { semiconductor } \\
\text { companies founded } \\
\text { 1978-1985. }\end{array}$ & Survival rates do not vary between regions. & $\mathrm{L}: 0$ \\
\hline Staber (1998) & $\begin{array}{l}\text { Survival of German } \\
\text { textile firms founded } \\
\text { 1945-1993. }\end{array}$ & $\begin{array}{l}\text { Hazard rate of firm mortality positively associated with } \\
\text { number of local firms in the industry at the time of } \\
\text { founding and at the time of termination. }\end{array}$ & $\mathrm{L}:-$ \\
\hline
\end{tabular}

Table 1. Empirical Studies on the Effect of Urbanization and Localization (Cluster) Economies on Firm Performance 